\title{
THERMAL ANALYSIS OF EPOXY BASED COCONUT FIBER-ALMOND SHELL PARTICLE REINFORCED BIOCOMPOSITES
}

\author{
Arun Kumar Chaudhary, P.C. Gope, V.K. Singh, \\ Alka Verma, Ajay Rajiv Suman
}

S u m m a r y

In this research, the suitability of almond shell and coconut fiber as a renewable agricultural residue for manufacturing of biocomposite to be used as a replacement of wood was investigated. The use of agriculture waste as a reinforcement in composite may result in several environmental and socioeconomic benefits. Biocomposite containing different weight percentage of almond shell particle $(10,20,30,40$ and $50 \mathrm{wt} \%)$ and coconut fiber $(2,4$ and $6 \mathrm{wt} \%)$ mixed with $20 \mathrm{wt} \%$ of almond shell particles were made using epoxy resin and $0.5 \mathrm{wt} \%$ of Tricresyl Phosphate. Thermal stability test and morphology (SEM) of the biocomposite were determined.

Keywords: Particle-reinforcement, almond shell, coconut fiber, microstructure, thermal analysis.

$$
\begin{aligned}
& \text { Analiza cieplna biokompozytów epoksydowych umacnianych łuskami migdałowca } \\
& \text { i włóknami kokosowymi } \\
& \text { S t r e s z c z e n i e }
\end{aligned}
$$

W artykule przedstawiono analizę wyników badań trwałości materiałów biokompozytowych umacnianych łuskami migdałowca i włóknami kokosowymi, używanych jako zamienniki drewna. Zastosowanie odpadów rolniczych jako elementów umacniających materiały kompozytowe pozytywnie oddziałuje zarówno na środowisko naturalne, jak i kryteria ekonomiczne ich producentów. W ba-daniach stosowano materiały biokompozytowe o zawartości cząstek łusek migdałowca od 10 do $50 \%$ mas. oraz włókien kokosowych 2, 4 i 6\% mas. Osnową wytworzonych kompozytów była żywica epoksydowa z dodatkiem fosforanu trikrezylowego 0,5\% mas. Wykonano badania stabilności cieplnej wytworzonych biokompozytów oraz ich mikrostruktury przy zastosowaniu mikroskopu skaningowego SEM.

Słowa kluczowe: materiały biokompozytowe, cząstki łusek migdałowca, włókna kokosowe, mikrostruktura, analiza cieplna

\section{Introduction}

The low cost of manufacturing, high specific stiffness and flexibility make biofibers as a attractive fillers or reinforcers to the manufacturers. The use

Address: Arun Kumar CHAUDHARY, Department of Industrial \& Production Engineering, P.C. GOPE, V.K. SINGH, Ajay Rajiv SUMAN, Department of Mechanical Engineering, Alka VERMA, Department of Vegetable Science, G.B. Pant University of Agricultural and Technology, Pantnagar, India 263 145, Corresponding author. Tel.: +91 9412451444, e-mail : aruncdme@gmail.com (Arun Kumar Chaudhary) 
of such materials in composites has increased due to their relative low cost, their ability to recycle and for the fact that they can compete well in terms of strength per weight of material. This century has witnessed increasing demands for the utilization of plastics as important raw materials and more than $80 \%$ of which are thermoplastics which are used for composite manufacturing. Plastic composites reinforced with Biofiber are gaining more and more acceptance in structural applications. Due to the development in the technology connected with consumer demands and expectations continues to increase demands of resources, leading to major issues of environmental sustainability and material availability [1].

The raw material demand of the forest industry has continued to grow. On one hand, approximately $95 \%$ of all ligno-cellulosic material available for particleboard production is wood [2]. While forests, the major sources of wood supply are declining another side at the alarming rate of 13.0 million ha each year in developing countries [3]. This problem along with the necessity of conserving natural resources has led to great efforts regarding the use of agricultural residues in particleboard manufacturing. Agricultural residues will play an important role in the future of the forest industry [4]. Renewable biomass are mostly accepted as waste materials and are mostly burnt in the field or ploughed into the soil. It seems that the use of renewable biomass in the forest industry will gain more importance. There are more than 30 plants that can be utilized as renewable biomass in production of particleboard all over the world [5]. Almonds (Prunus amygdalus L.) are a very important crop throughout the world's temperate regions [6]. Worldwide almond production in 2009 was about 2.31 million tons from a total of 1.7 million ha [7]. Almond shell accounts for $35-75 \%$ of the total fruit weight [8]. Consequently, around 0.8-1.7 million tons of almond shell is left annually. Almond shell, an agricultural residue, is the ligno-cellulosic material forming the thick endocarp or husk of the almond fruit that is separated from fruit upon processing the fruit to obtain the edible seeds is separated and since they have no important industrial usages are normally incinerated or dumped [9]. Coconut, Cocos nucifera, shell is one of the most important natural fillers produced in tropical countries like Malaysia, Indonesia, Thailand, and Sri Lanka. Composites of high strength coconut filler can be used in the broad range of applications as marine cordage, building materials, furniture, fishnets and other household appliances. Coir fiber is obtained from the coconut husk. Coir fiber is one of the hardest natural fibers due to the presence of its high content of lignin. The high content of lignin in coir fiber made the fiber tougher and stiffer, compared to other fibers [10]. Burning agricultural residues causes environmental problems such as soil erosion, air pollution and decreases soil biological activity. Utilizing agricultural residues not only prevents environmental concerns but also can mean farmers second income from plantation [11]. The epoxy resin (CY-230) has been used as a matrix material for the preparation of biocomposite due to its good heat 
resistance and electric insulation property $[12,13]$. Also, multifunctional epoxy resins are more resistant to the heat [14].

The main objective of the present study is to make some observations on the addition of almond shell particles and coconut fiber at different weight ratios, using thermal analysis and electron microscopy such that the research findings can lead to the optimized mixing of almond particles and coconut fiber to get desired properties and it can reduce the environmental hazards and deforestation.

\section{Material and methods}

\subsection{Material}

The raw material of this study included almond (Prunus amygdalus L.) shell collected from Jammu, India, coconut (Cocos nucifera) fiber collected from local market and tricresyl phosphate that was provided by Loba Chemical Pvt. Ltd., 107 Wodehouse Road, Mumbai. Almond shells were first cleaned from dirt and impurities then crushed into small pieces and dried in the oven up to $70^{\circ} \mathrm{C}$ for two hours for removing the moisture. Then the dried almond shells were converted into the powder form in the wiley mill. The average size of the almond shell particles were $1.18 \mu \mathrm{m} \pm 0.06 \mu \mathrm{m}$. The coconut fiber collected from the local market were dried in the oven up to $70^{\circ} \mathrm{C}$ and were cut into small pieces of sizes in the range of $2-3 \mathrm{~mm}$ with the average diameter was $21 \mu \mathrm{m}$ $\pm 4 \mu \mathrm{m}$. Tricresyl phosphate has been used as a plasticizer, flame retardant and for the waterproofing of materials. The hardener (HY-951) was mixed 8\% (by weight) with resin (CY-230) and $0.5 \mathrm{wt} \%$ tricresyl phosphate has been selected as plasticizer and fire retardant additive. The addition of tricresyl phosphate increased the ultimate and failure strength as compared to unfilled epoxy significantly. Material with $0.5 \mathrm{wt} \%$ of tricresyl phosphate showed best results as compared to other wt $\%$ of tricresyl phosphate mixed with epoxy. The solution obtained by mixing tricresyl phosphate, almond shell particles and coconut fiber in resin is kept in the furnace at a temperature of $90 \pm 10^{\circ} \mathrm{C}$ for two hours. The electric furnace (Temperature Range $0-600^{\circ} \mathrm{C}$ ) is used for this purpose. The solution was taken out from the electric furnace after an interval of 30 minutes and remixed by mechanical stirrer at high speed. After two hours the whole solution was taken out from the furnace and allowed to cool to a temperature of $45^{\circ} \mathrm{C}$. When a temperature of $45^{\circ} \mathrm{C}$ was attained the hardener HY-951 was mixed immediately. The viscous solution so obtained is poured into different moulds for sample preparation.

\subsection{Thermal analysis}

Thermal analysis is a branch of materials science where the properties of materials are studied as they change with temperature. The DTA-DTG-TG 
analysis of all the samples was carried out using TG analyzer (EXSTAR TG/DTA 6300) at Indian Institute of Technology, Roorkee (IITR) by heating the sample in air $(200 \mathrm{~mL}$ min- 1$)$ at $10^{\circ} \mathrm{C}$ min- 1 from 0 to $700^{\circ} \mathrm{C}$ with reference as alumina powder.

Scanning electron microscope (SEM) - The state of dispersion of almond shell particles and coconut fibers into the resin matrix plays a significant role on the machining, thermal and mechanical properties of the biocomposite. Various methods such as SEM, TEM and DSC etc. can be used to evaluate the particle dispersion in the composite.

In the current work the SEM studies has been done to see the dispersion of almond shell particles and coconut fibers in resin. The images are obtained through microscopic investigation with JSM-66101V scanning machine at G.B. Pant Univ. of Ag. \& Tech., Pantnagar. To obtained the scanning electrons micrographs square samples are cut from the tensile fractured surface and are gold coated to avoid the artifacts associated with sample charging. The accelerated voltage was $5 \mathrm{kV}$.

\section{Results and discussion}

\subsection{Thermal Analysis}

Figure 1 shows result of thermogram etric analysis of $10 \mathrm{wt} \%$ of almond shell particles based biocomposite. Decomposition of this biocomposite has been accomplished under five stages ranging from 229 to $514^{\circ} \mathrm{C}$ with corresponding rate of decompositions ranging 0.27 to $0.46 \mathrm{mg} / \mathrm{min}$. Prior to $200^{\circ} \mathrm{C}$, the weight loss of $6.52 \%$ may be attributed to the expulsion of the moisture and low molecular mass biomolecules associated with $10 \mathrm{wt} \%$ of almond shell particles. The maximum rate of decomposition of $0.89 \mathrm{mg} / \mathrm{min}$ was observed at $404^{\circ} \mathrm{C}$. Such decomposition has been supported with a broad heat of fusion $-11.2 \mathrm{~J} / \mathrm{mg}$ centered in the temperature ranging 292 to $522^{\circ} \mathrm{C}$ with DTA signal 49.2 to $107.9 \mu \mathrm{V}$. The decomposition of this biocomposite had been concluded at $550^{\circ} \mathrm{C}$ leaving char residue $2.5 \%$.

Increase in concentration of the filler to $20 \mathrm{wt} \%$ of almond shell particles has contributed a marginal modification in the thermal stability of the biocomposite (Fig. 2). Decomposition of $20 \mathrm{wt} \%$ of almond shell particles had been progressed under five steps ranging 225 to $533^{\circ} \mathrm{C}$ with rate of degradation 0.23 to $0.42 \mathrm{mg} / \mathrm{min}$. This has rendered maximum rate of decomposition $1.04 \mathrm{mg} / \mathrm{min}$ at $360^{\circ} \mathrm{C}$. A broad DTA representing the heat of fusion of - $10.6 \mathrm{~J} / \mathrm{mg}$ of the $20 \mathrm{wt} \%$ of almond shell particles had been appeared at temperature ranging 292 to $615^{\circ} \mathrm{C}$. 


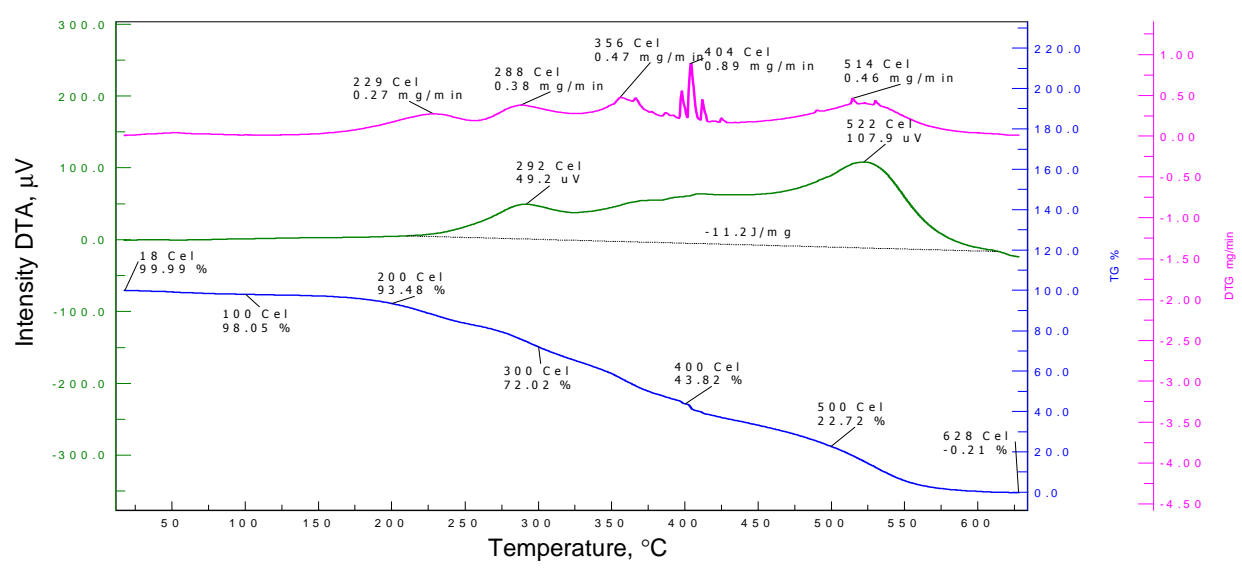

Fig. 1. DTA-DTG-TG of $10 \mathrm{wt} \%$ almond shell particles based biocomposite

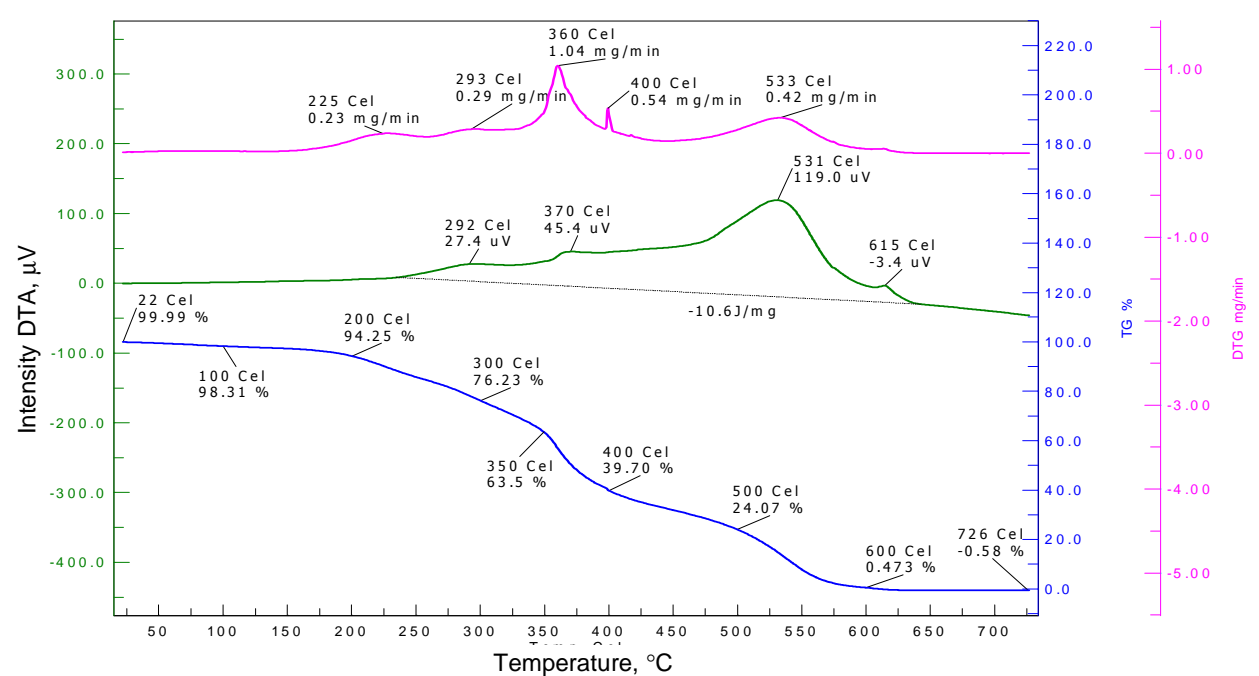

Fig. 2. DTA-DTG-TG of $20 \mathrm{wt} \%$ almond shell particles based biocomposite

This has been supported with a sharp signal of $119 \mu \mathrm{V}$ at $531^{\circ} \mathrm{C}$. Prior to $200^{\circ} \mathrm{C}$, the weight loss of $5.75 \%$ may be assigned to the loss of moisture and low molecular mass biomolecules from $20 \mathrm{wt} \%$ of almond shell particles.

Figure 3 shows result of thermogrametric analysis of $30 \mathrm{wt} \%$ of almond shell particles. This sample shows four step decomposition ranging 225 to $518^{\circ} \mathrm{C}$ with rate of decomposition ranging 0.24 to $0.38 \mathrm{mg} / \mathrm{min}$. This has been supported with a DTA corresponding to heat of fusion of $-13.4 \mathrm{~J} / \mathrm{mg}$. The sample shows DTA signal of $119.5 \mu \mathrm{V}$ at $515^{\circ} \mathrm{C}$. Prior to $200^{\circ} \mathrm{C}$, the weight loss of $6.53 \%$ associated with this sample may be assigned to the loss of moisture 
and residual low molecular mass biomolecules. The decomposition of $30 \mathrm{wt} \%$ of almond shell particles had been ended at $728^{\circ} \mathrm{C}$ leaving char residue $2.264 \%$.

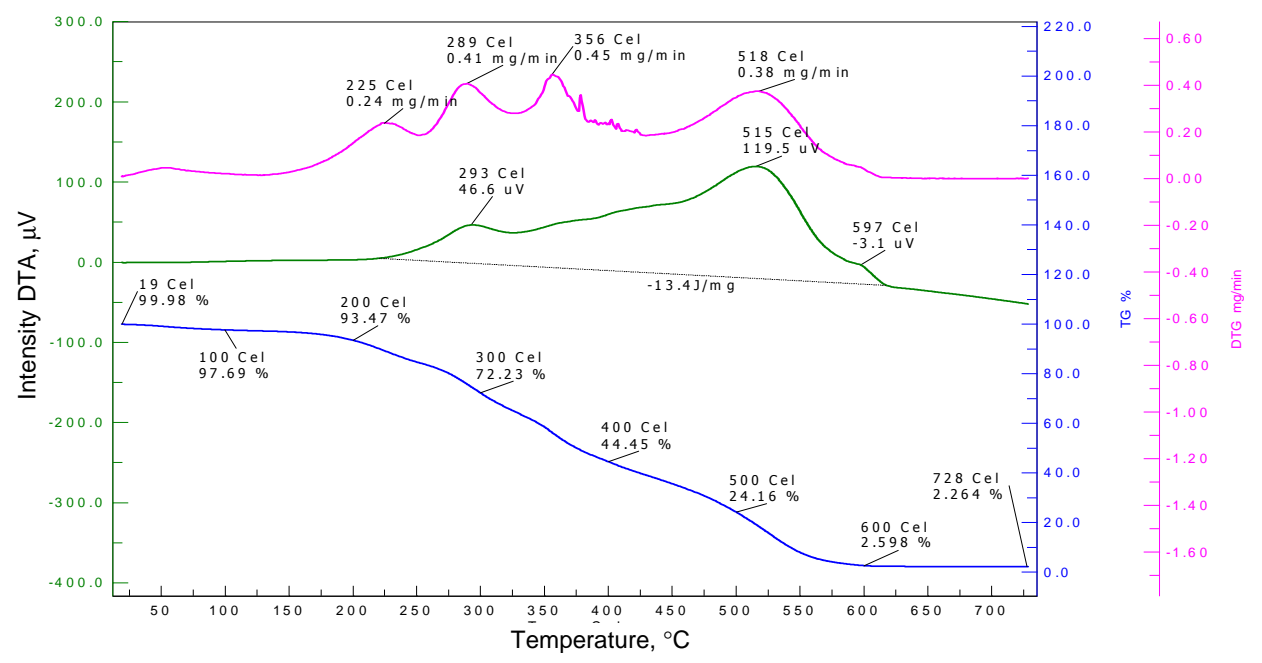

Fig. 3. DTA-DTG-TG of $30 \mathrm{wt} \%$ almond shell particles based biocomposite

Decomposition of $40 \mathrm{wt} \%$ of almond shell particles had been associated in four steps ranging 226 to $497^{\circ} \mathrm{C}$ with rate of decomposition 0.24 to $0.41 \mathrm{mg} / \mathrm{min}$. This has been supported with a DTA ranging 294 to $583^{\circ} \mathrm{C}$ with a heat of fusion of $-13.5 \mathrm{~J} / \mathrm{mg}$. Prior to $200^{\circ} \mathrm{C}$, the residual weight loss of $7.49 \%$ may be associated with the loss of moisture and low molecular mass biomolecules. Decomposition of $40 \mathrm{wt} \%$ of almond shell particles had been ended at $590^{\circ} \mathrm{C}$ leaving char residue $3.5 \%$ as shown in Figure 4.

Figure 5 shows that $50 \mathrm{wt} \%$ of almond shell particles represents four step decompositions with temperature range 228 to $492^{\circ} \mathrm{C}$ corresponding to rate of decomposition 0.24 to $0.41 \mathrm{mg} / \mathrm{min}$ with maximum rate of decomposition $0.70 \mathrm{mg} / \mathrm{min}$ at $288^{\circ} \mathrm{C}$. This has been supported with a broad DTA corresponding to heat of fusion $-14.2 \mathrm{~J} / \mathrm{mg}$ with peak temperature $490^{\circ} \mathrm{C}$ at $133.3 \mu \mathrm{V}$. Prior to $200^{\circ} \mathrm{C}$, the residual loss of $6.89 \%$ in the weight of the sample may be assigned to the expulsion of moisture and low molecular mass biomolecules. Decomposition of $50 \mathrm{wt} \%$ of almond shell particles has been ended at $727^{\circ} \mathrm{C}$ leaving char residue $0.13 \%$. 


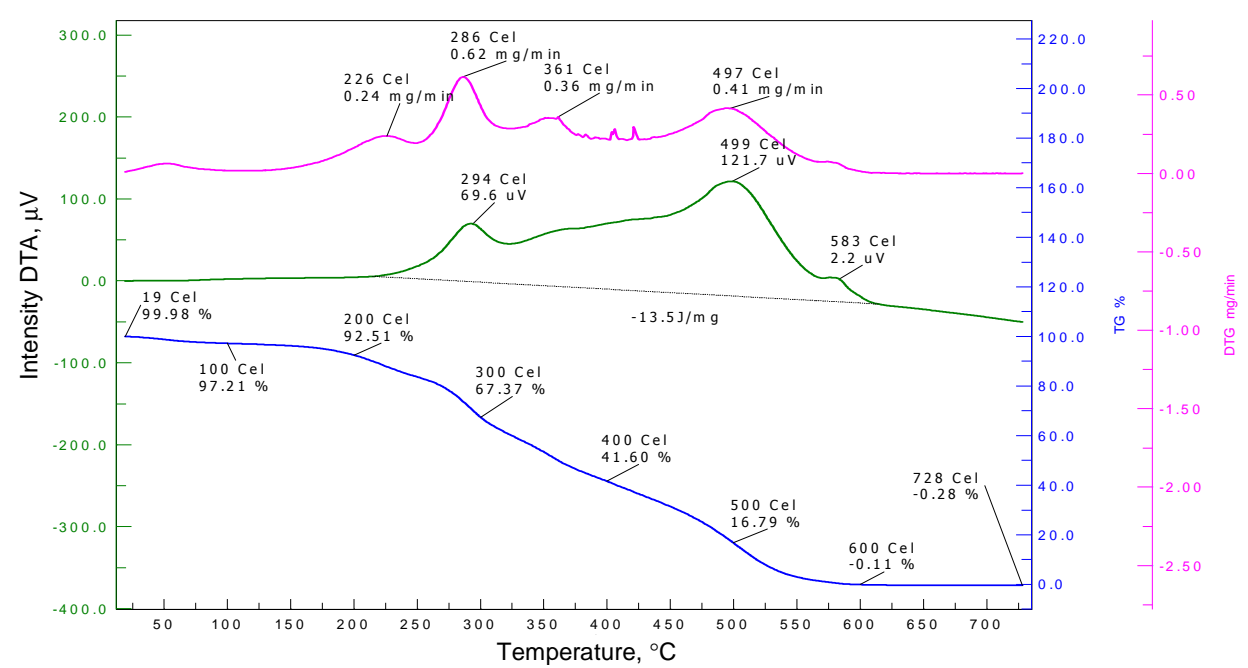

Fig. 4. DTA-DTG-TG of $40 \mathrm{wt} \%$ almond shell particles based biocomposite

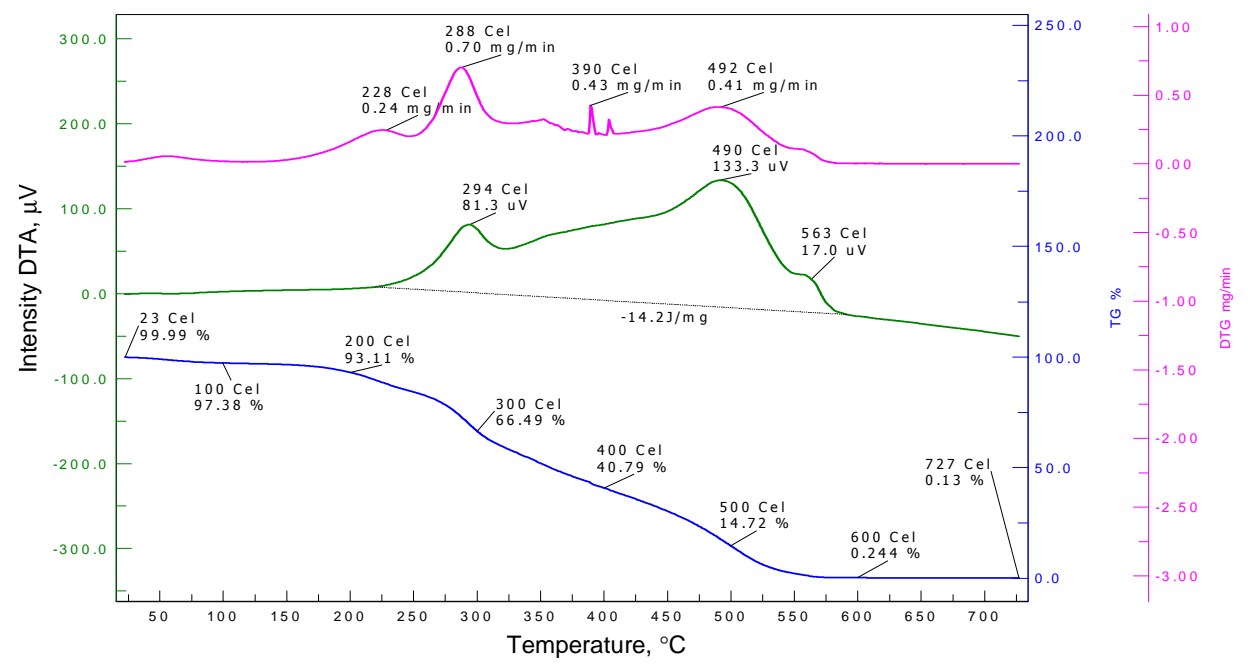

Fig. 5. DTA-DTG-TG of $50 \mathrm{wt} \%$ almond shell particles based biocomposite

Figures 6 to 8 represent the effect of coconut fiber as co-filler on the thermal stability of the biocomposites. In order to have comparable results, an almond shell particle/ Epoxy composite fabricated at $20 \mathrm{wt} \%$, has been selected for further modification with different filler concentration of the coconut fiber ranging 2 to $6 \mathrm{wt} \%$.

Figure 6 shows the plot from thermogrametric analysis of $2 \mathrm{wt} \%$ of coconut fiber, which shows three step decompositions ranging 235 to $492^{\circ} \mathrm{C}$ with rate of decomposition 0.31 to $0.45 \mathrm{mg} / \mathrm{min}$ and peak temperature $287^{\circ} \mathrm{C}$ at 
$0.72 \mathrm{mg} / \mathrm{min}$. This has been supported with a DTA ranging 293 to $493^{\circ} \mathrm{C}$ with heat of fusion $-14.3 \mathrm{~J} / \mathrm{mg}$. The weight loss of $6.09 \%$ prior to $200^{\circ} \mathrm{C}$ associated with the biocomposite may be assigned to the loss of moisture and low molecular mass biomolecules. The decomposition of composite has been terminated at $726^{\circ} \mathrm{C}$ leaving char residue $0.37 \%$.

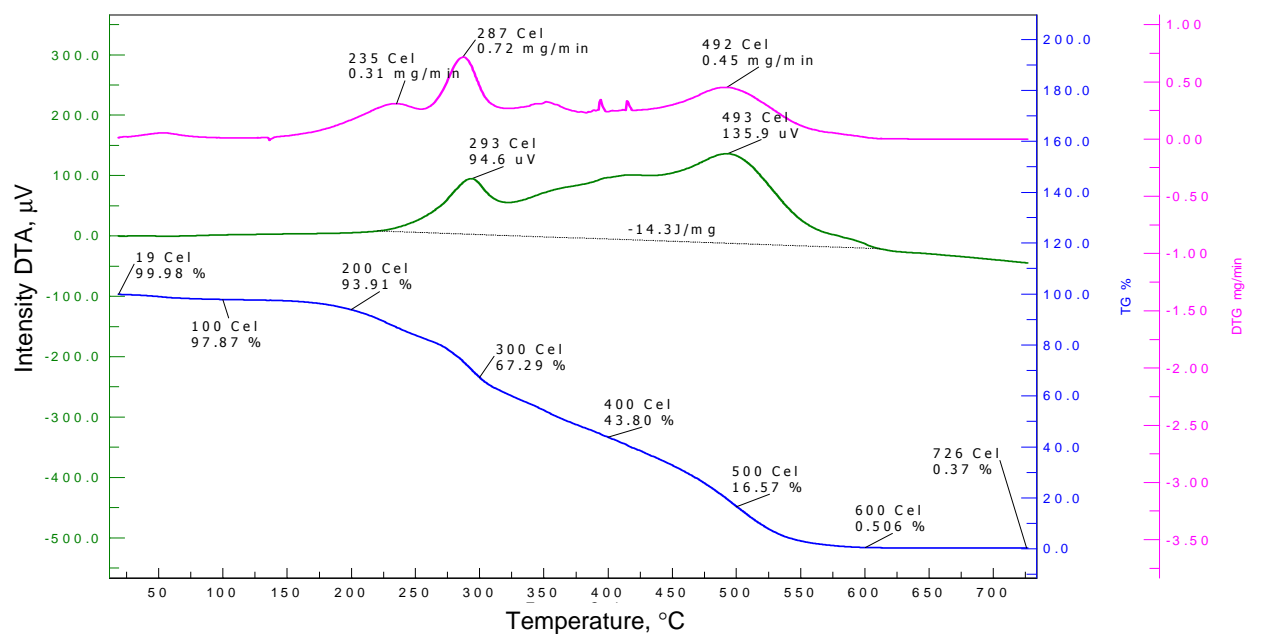

Fig. 6. DTA-DTG-TG of $20 \mathrm{wt} \%$ almond shell particles and $2 \mathrm{wt} \%$ of coconut fiber based biocomposite

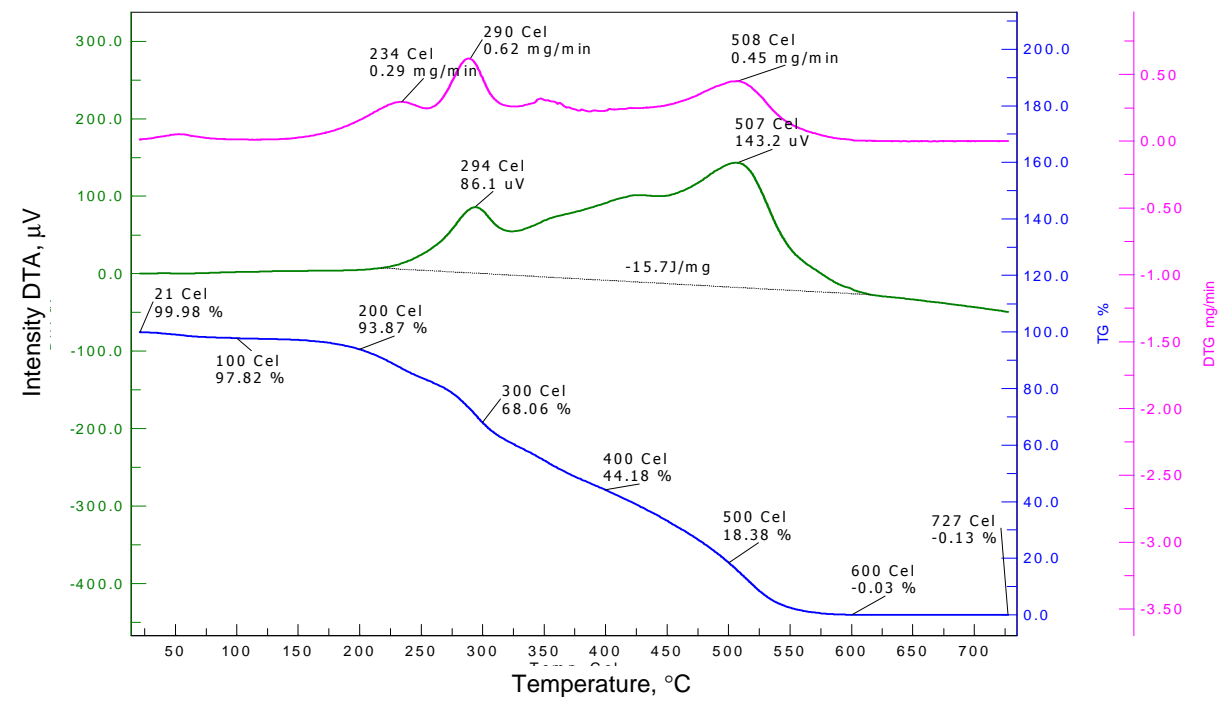

Fig. 7. DTA-DTG-TG of $20 \mathrm{wt} \%$ almond shell particles and $4 \mathrm{wt} \%$ of coconut fiber based biocomposite 
Further increase in the concentration of coconut fibers to 4 wt $\%$ has rendered the composite with three step decompositions ranging 234 to $508^{\circ} \mathrm{C}$ with rate of decomposition ranging from 0.29 to $0.45 \mathrm{mg} / \mathrm{min}$. This has been supported with a DTA with peak temperature of $507^{\circ} \mathrm{C}$ at $143.2 \mu \mathrm{V}$ and a heat of fusion of $-15.7 \mathrm{~J} / \mathrm{mg}$ centered at the temperature range 294 to $507^{\circ} \mathrm{C}$. Prior to $200^{\circ} \mathrm{C}$, a weight loss of $6.13 \%$ associated with biocomposite may be assigned to the loss of moisture and low molecular mass biomolecules. Decomposition of the composite has ended at $590^{\circ} \mathrm{C}$ leaving char residue $0.9 \%$ (Fig. 7).

Figure 8 shows the effect of $6 \mathrm{wt} \%$ of coconut fiber on the thermal stability of the biocomposite. Decomposition of biocomposite had been progressed in four steps with temperature ranging from 236 to $517^{\circ} \mathrm{C}$ corresponding to rate of decomposition 0.28 to $0.43 \mathrm{mg} / \mathrm{min}$. Decomposition of the composite has been associated with heat of fusion of $-14.1 \mathrm{~J} / \mathrm{mg}$ centered within temperature range 294 to $601{ }^{\circ} \mathrm{C}$. Prior to $200^{\circ} \mathrm{C}$, a weight loss of $6.19 \%$ associated with the biocomposite may be assigned to the loss of moisture and low molecular mass biomolecules. The decomposition of the biocomposite had ended at $590^{\circ} \mathrm{C}$ leaving char residue $0.95 \%$.

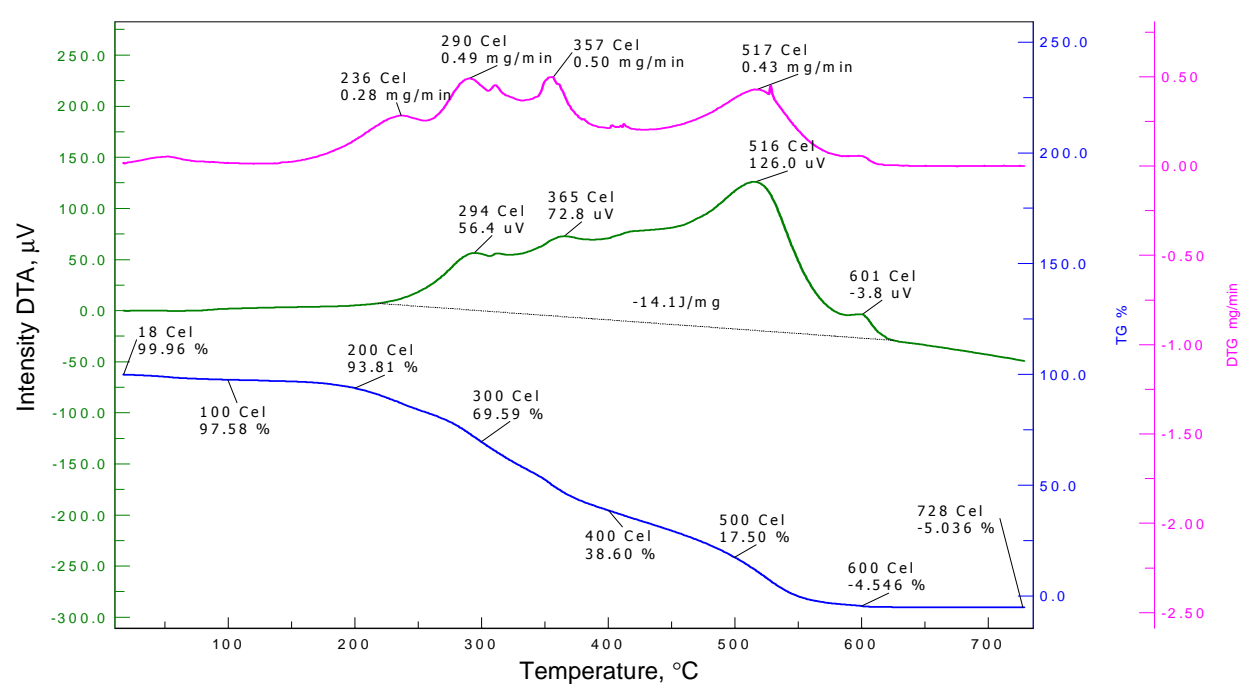

Fig. 8. DTA-DTG-TG of $20 \mathrm{wt} \%$ almond shell particles and $6 \mathrm{wt} \%$ of coconut fiber based biocomposite

The thermal data reveals that the almond shell particles had rendered a marginal increase in the thermal stability of the biocomposites. The maximum decomposition of the composites ranged in the temperature 286 to $404^{\circ} \mathrm{C}$ 
with a narrow rate of decomposition 0.62 to $0.89 \mathrm{mg} / \mathrm{min}$. This was supported with DTA ranging 490 to $615^{\circ} \mathrm{C}$ with heat of fusion ranging -14.2 to $-10.6 \mathrm{~J} / \mathrm{mg}$. Prior to $200^{\circ} \mathrm{C}$, all the samples display loss in moisture and low molecular mass biomolecules ranging 5.75 to $7.49 \%$ and leave the respective char residue ranging 0.13 to $3.5 \%$ at temperature ranging 550 to $727404^{\circ} \mathrm{C}$. Modification of the composite with addition of coconut fiber contributed marginal control in the rate of decomposition, heat of fusion of the composites, that ranged from 0.28 to $0.62 \mathrm{mg} / \mathrm{min},-14.1$ to $15.7 \mathrm{~J} / \mathrm{mg}$ and char residue ranging 0.37 to $0.95 \%$ at temperature range 590 to $726^{\circ} \mathrm{C}$.

Addition of coconut fiber in the almond shell particle reinforced epoxy based biocomposite increased the thermal stability as compared to the pure almond shell particle based biocomposites.

\section{Scanning Electron Microscope (SEM)}

In the present investigation scanning electron microscope has been carried out for hybrid composite containing different weight percentage of almond shell particles and coconut fibers to evaluate the particle size, matrix interface and dispersion of the almond shell particles and coconut fibers in the epoxy resin matrix as well as the fracture behaviour of the biocomposite.

The SEM micrographs of tensile fractured surface of 10, 20, 30, 40 and 50 wt $\%$ of almond shell particles and 2, 4 and $6 \mathrm{wt} \%$ of coconut fiber mixed with $20 \mathrm{wt} \%$ of almond shell particle based biocomposites were taken.

Figures 9 and 10 shows the micrograph of tensile fractured surface for 10 $\mathrm{wt} \%$ and $30 \mathrm{wt} \%$ almond shell particle biocomposite at 2,000 X. The high magnification micrograph (X2000) of 10 wt\% almond shell particle biocomposite shows the particle size varies between 1.020 to $1.253 \mu \mathrm{m}$. Figure 10 also indicates some cavity like pattern. These cavities are produced due to the pullout of the almond shell particles. From Figure 9 and 10, it can be seen a mixture of smooth and rough surface. It indicates ductile failure.

The pull out failures are more clear in Figure 11 where $50 \mathrm{wt} \%$ almond shell particles were mixed with the resin. From the above micrographs, it is clear that almond shell particulate biocomposite failed due to pull out of the particles, either due to poor adhesion with the matrix or due to smaller particle size.

The tensile failure behaviour due to further addition of coconut fiber can be seen in the Figure 12 for $6 \mathrm{wt} \%$ of coconut fiber mixed in $20 \mathrm{wt} \%$ of almond shell particle. Micrographs show that the fiber diameter varies from 16.125 to $25.864 \mu \mathrm{m}$. In all figures particle pull out and fiber either pull out or broken perpendicular to the fiber surface is seen. 


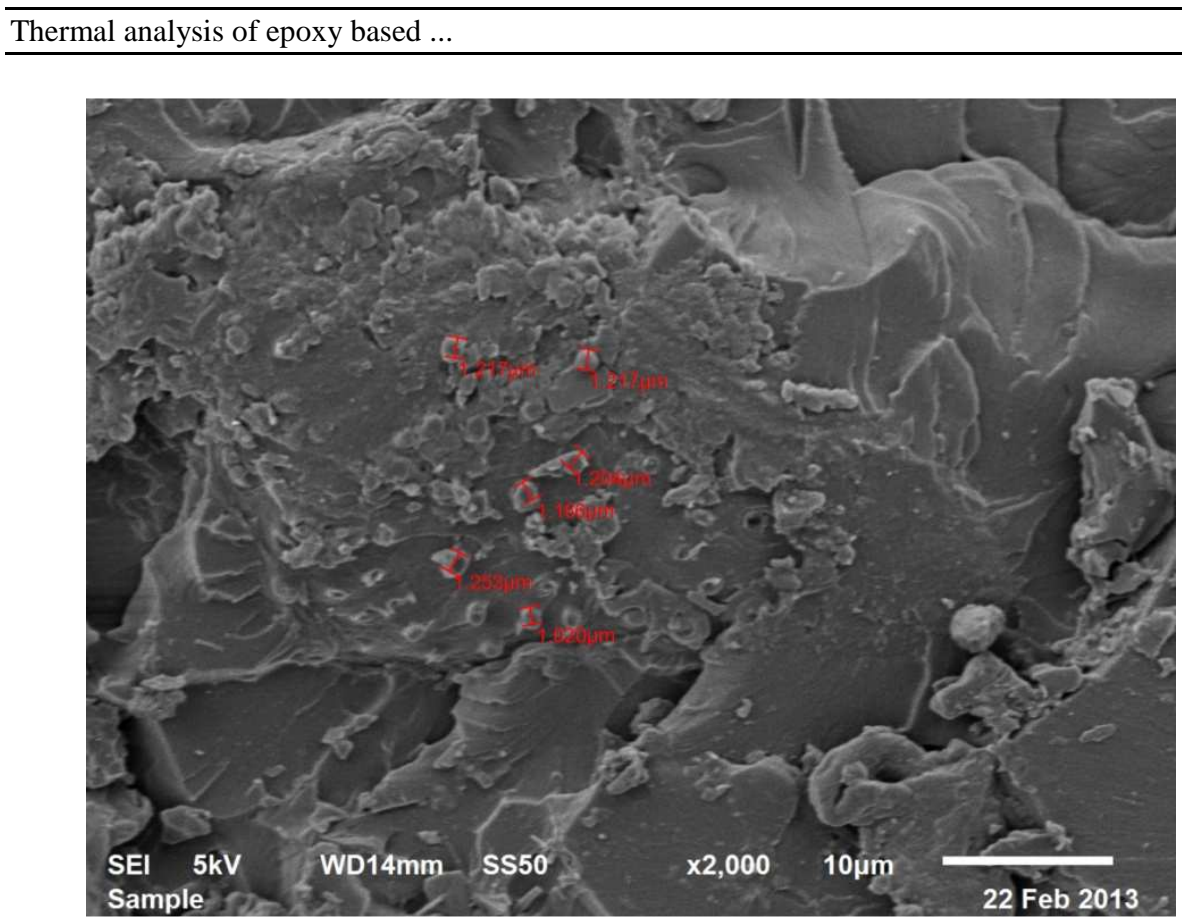

Fig. 9. Scanning electron micrograph for (CY-230 + $8 \mathrm{wt} \%$ HY-951+ $0.5 \mathrm{wt} \%$ TCP $+10 \mathrm{wt} \% \mathrm{AP})$

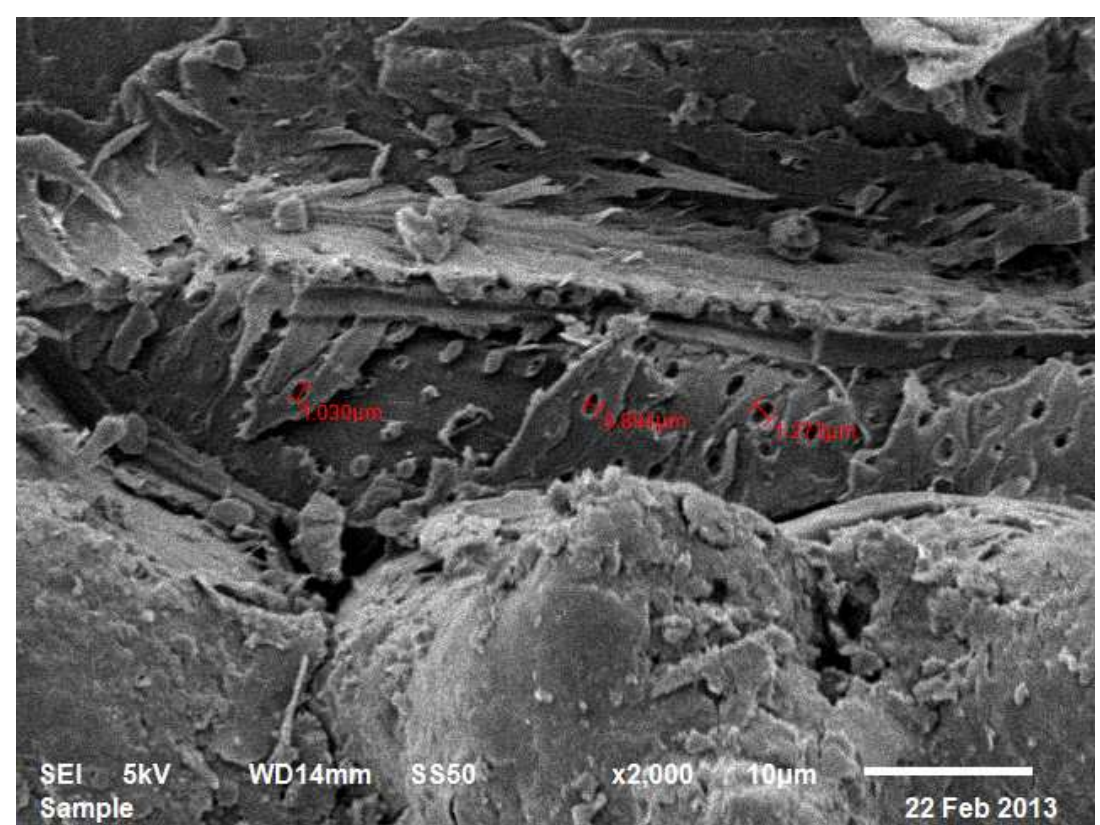

Fig. 10. Scanning electron micrograph for (CY-230 + $8 \mathrm{wt} \%$ HY-951+ $0.5 \mathrm{wt} \%$ TCP $+30 \mathrm{wt} \% \mathrm{AP}$ 


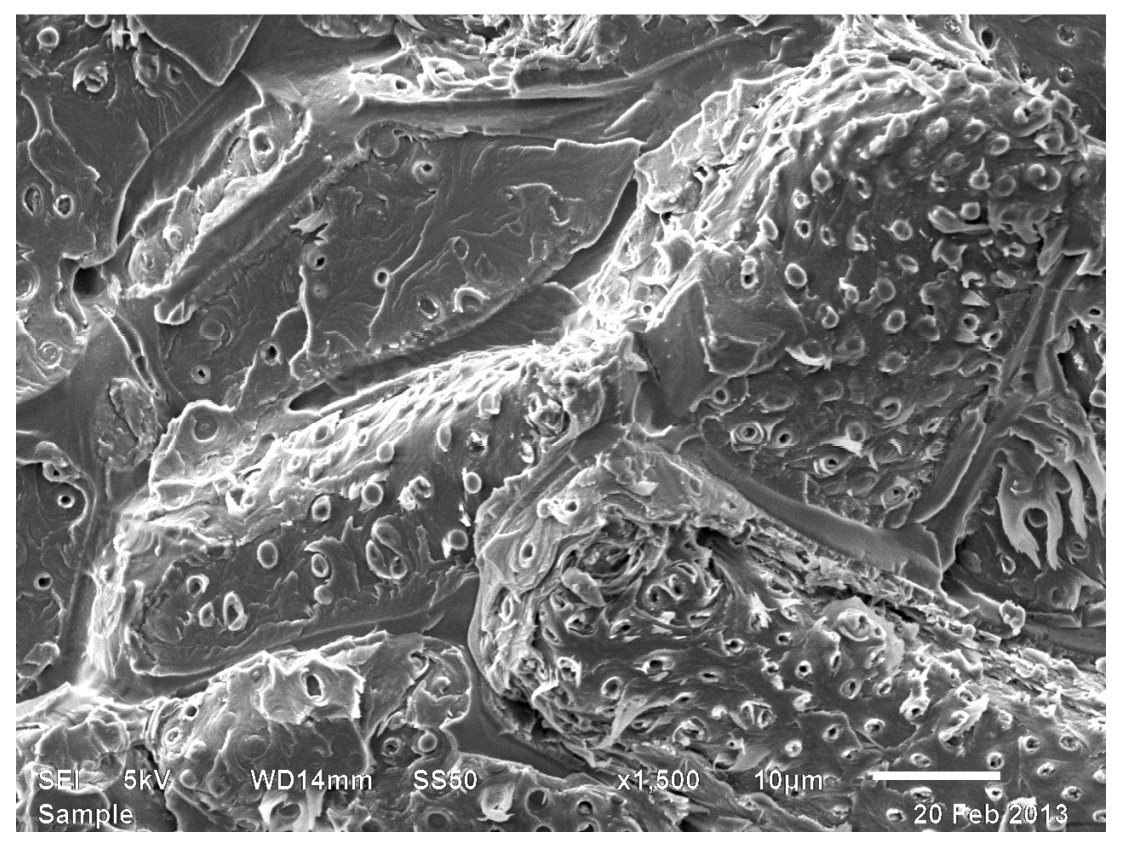

Fig. 11. Scanning electron micrograph for (CY-230 + $8 \mathrm{wt} \% \mathrm{HY}-951+0.5 \mathrm{wt} \% \mathrm{TCP}$ $+50 \mathrm{wt} \% \mathrm{AP})$

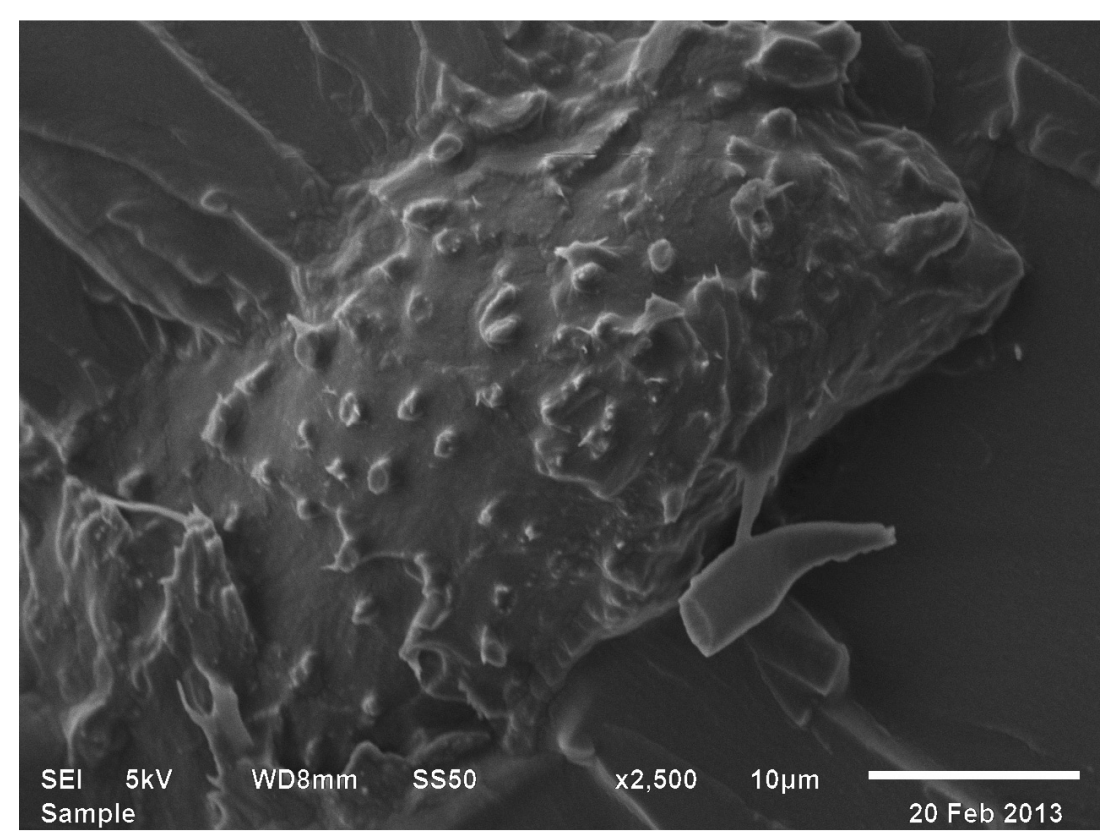

Fig. 12. Scanning electron micrograph for $(\mathrm{CY}-230+8 \mathrm{wt} \% \mathrm{HY}-951+0.5 \mathrm{wt} \% \mathrm{TCP}$ $+20 \mathrm{wt} \% \mathrm{AP}+6 \mathrm{wt} \% \mathrm{CF})$ 


\section{Conclusions}

1. Almond shell particle size varies between 1.020 to $1.253 \mu \mathrm{m}$. Almond shell particulate biocomposite failed due to pull out of the particles. Coconut fiber diameter varies from 16.125 to $25.864 \mu \mathrm{m}$. The perpendicular failure or shear failure of the fiber indicates that the interfacial bond strength is high.

2. Increase in concentration of almond shell particles has contributed a marginal modification in the thermal stability of the biocomposite. Addition of coconut fiber has contributed marginal control in the rate of decomposition. Addition of coconut fiber in the almond shell particle reinforced epoxy based biocomposite increased the thermal stability as compared to the pure almond shell particle based biocomposites.

\section{Acknowledgment}

The authors are thankful to the Dean, College of Technology, Pantnagar for providing financial and all the necessary facilities for this research work.

\section{References}

[1] O. FARUK, K. ANDRZEJ, H.P. BLEDZKI FINK, M. SAIN: Biocomposites reinforced with natural fibers: 2000-2010. Progress in Polymer Science, 37(2012)11, 1552- 1596.

[2] G. NEMLI, S. YILDIZ, E.D. GEZER: The Potential for using the needle litter of Scotch pine (Pinussylvestris L.) as a raw material for particleboard manufacturing. Bioresour Technol., 99(2008), 6054-6058.

[3] A. ASHORI: Non-wood fibers- a potential source of raw material in papermaking. Polym-Plast Technol Eng., 45(2006)10, 1133-1136.

[4] C. GULER, Y. COPUR, C. TASCIOGLU: The manufacture of particleboards using mixture of peanut hull (Arachishypoqaea L.) and European black pine (Pinusnigra Arnold) wood chips. Bioresour Technol., 99(2008), 2893-2897.

[5] I. BEKTAS, C. GULER, H. KALAYCIOGLU, F. MENGELOGLU, M. NACAR: The manufacture of particleboards using sunflower stalks (Helianthus annuus L.) and poplar wood (Populusalba L.). J Compos Mater., 39(2005)5, 467-473.

[6] C.A. LEDBETTER: Shell cracking strength in almond (Prunus dulcis [Mill.] D.A.Webb.) and its implication in uses as a value-added product. Bioresour Technol., 99(2008), 5567-5573.

[7] http://faostat.fao.org/faostat/ FAOSTAT data. 2010. Accessed September 2010.

[8] A. EBRINGEROVA, Z. HEROMADKOVA, Z. KOSTALOVA, V. SASINKOVA: Chemical valorization of agricultural by-products: isolation and characterization of xylan based antioxidants from almond shell biomass. Bioresources, 3(2008), 60-70.

[9] M. URRESTARAZU, G.A. MARTINEZ, M.D. CARMEN SALAS: Almond shell waste: possible local rockwool substitute in soilless crop culture. Sci Hortic., 103(2005), 453-460. 
[10] H.P.S.A. KHALIL, M.S. ALWANI, A.K.M. OMAR: Chemical composition, anatomy, lignin distribution, and cell wall structure of Malaysian plant waste fibers. Bioresources., 1(2006)2, 220-232.

[11] Y. COPUR, C. GULER, M. AKGUL, C. TASCIOGLU: Some chemical properties of hazelnut husk and its suitability for particleboard production. Build Environ., (2007), 2568-2572.

[12] M.K. SHREE, J.S.E. PRADEEP, K.S. ANANDA, M.J. UMAPATHY: Development of dimethylsiloxane based tetraglycidyl epoxy nanocomposites for high performance, aerospace and advanced engineering applications. Prog. Org. Coat., 74(2012), 19-24.

[13] S.M. SANCHEZ, P. PAGES, T. LACORTE, K. BRICENO, F. CARRASCO: Curing FTIR study and mechanical characterization of glass bead filled trifunctional epoxy composites. Compos Sci. Technol., 67(2007), 1974-1985.

[14] I. BLANCO, L. OLIVERI, G. CICALA, A. RECCA: Effect of novel reactive toughening agent on thermal stability of epoxy resin. J. Therm. Anal. Calorim., 108(2012), 685-693.

Received in March 2013 